\title{
KAJIAN FITOKIMIA DAN AKTIFITAS ANTIHIPERKOLESTEROLEMIA EKSTRAK KETUMBAR (Coriandrum sativum L) PADA MENCIT SWISS WEBSTER
}

\author{
Study On Phytochemical And Anti-Hypercholesterolemic Activity Of Coriander Extract \\ (Coriandrum sativum L) In Swiss Webster Mice \\ Karolina Rosmiati*1, Berliana Naomi Rumondang Sari Aritonang ${ }^{1}$ \\ Akademi Kesehatan John Paul II Pekanbaru \\ * Koresponden Email : karolina.rosmiati@akjp2.ac.id
}

DOI: https://doi.org/10.32382/mf.v16i2.1755

\section{ABSTRACT}

The results from previous studies showed that coriander (Coriandrum sativum L.) is effective for hypertension, antimicrobials and vaginal discharge, but in the wider community there are many traditional uses of coriander for other diseases such as diabetes mellitus, hypercholesterolemia, arthritis and inflammation. This research aims to determine an antihypercholesterolemic effect of coriander ethanol extract in decreasing total cholesterol levels and the best dose. The anti-hypercholesterolemic test used Swiss Webster male mice were divided into 4 groups, such as negative control, positive control ( simvastatin $1.3 \mathrm{mg} / \mathrm{kg} \mathrm{BW}$ ), coriander ethanol extract with a dose of $420 \mathrm{mg} / \mathrm{kg} \mathrm{BW}$ and a dose of 840 $\mathrm{mg} / \mathrm{kg} \mathrm{BW}$. The experimental animals were induced exogenously using high fat diet and propyltiouracil for 30-40 days. The parameters studied were total cholesterol levels measured by the CHOD-PAP method, on day 0 (before induction), day 30 (after induction) and day 7 (after treatment) to determine the initial, increase and decrease levels of cholesterol. Similarly, the average cholesterol level decrease in each group was $9.8 \mathrm{mg} / \mathrm{dL}$ (negative control), $63.6 \mathrm{mg} / \mathrm{dL}$ (positive control), $20.2 \mathrm{mg} / \mathrm{dL}$ (extract dose $420 \mathrm{mg} / \mathrm{kg} \mathrm{BW}$ ) and $39.4 \mathrm{mg} / \mathrm{dL}$ (extract dose of $840 \mathrm{mg} / \mathrm{kg} \mathrm{BW}$ ). The statistical tests results using Anova One way showed a significant difference on the cholesterol decreases in each group, with $p=0.000(p$ $<0.005$ ). It was concluded that providing coriander (Coriandrum sativum L.) extract reduces cholesterol levels in male Swiss webster mice, with the most effective dose for lowering cholesterol levels being 840 $m g / k g B W$.

Keywords : extract, seeds, coriander, anti-cholesterol

\begin{abstract}
ABSTRAK
Hasil dari penelitian sebelumnya diketahui bahwa ketumbar (Coriandrum sativum L.) memiliki efektifitas terhadap hipertensi, antimikroba dan keputihan, namun dimasyarakat luas masih banyak penggunaan ketumbar secara tradisional untuk penyakit lain seperti diabetes mellitus, hiperkolesterol, arthritis dan inflamasi. Penelitian ini bertujuan untuk mengetahui ada atau tidaknya efek antihiperkolesterolemia ekstrak etanol biji ketumbar dalam menurunkan kadar kolesterol total serta mengetahui dosis ekstrak etanol biji ketumbar yang paling baik dalam menurunkan kadar kolesterol total. Pengujian antihiperkolesterolemia menggunakan hewan uji Mencit Swiss Webster Jantan yang dibagi menjadi 4 kelompok yaitu kontrol negatif, kontrol positif (simvastatin 1,3 mg/kg BB), ekstrak etanol biji ketumbar dosis $420 \mathrm{mg} / \mathrm{kg}$ BB dan dosis $840 \mathrm{mg} / \mathrm{kg}$ BB. Hewan uji terlebih dahulu diinduksi secara eksogen dengan pemberian diet tinggi lemak dan propiltiourasil selama 30-40 hari. Parameter yang dilihat adalah kadar kolesterol total yang diukur dengan metode CHOD-PAP yaitu pada hari ke 0 (sebelum induksi), hari ke 30 (sesudah induksi) dan hari ke 7 (sesudah perlakuan) untuk mengetahui kadar awal, kadar kenaikan dan kadar penurunan kolesterol. Penurunan rata-rata kadar kolesterol tiap kelompok adalah 9,8 mg/dL (kontrol negatif) , 63,6 mg/dL (kontrol positif), 20,2 mg/dL (ekstrak dosis $420 \mathrm{mg} / \mathrm{kg} \mathrm{BB}$ ) dan 39,4 mg/dL (ekstrak dosis $840 \mathrm{mg} / \mathrm{kg} \mathrm{BB}$ ). Hasil uji statistik dengan Anova One way menunjukkan perbedaan bermakna penurunan kolesterol pada setiap kelompok yaitu $\mathrm{p}=0,000(\mathrm{p}<$ 0.005). Hasil penelitian ini dapat disimpulkan bahwa pemberian ekstrak biji ketumbar (Coriandrum sativum L.) dapat menurunkan kadar kolesterol pada mencit swiss webster jantan dimana Dosis Ekstrak biji ketumbar yang paling efektif menurunkan kadar kolesterol sebesar 840 mg/kg BB.
\end{abstract}

Kata kunci : ekstrak,biji,ketumbar,antihiperkolesterol 


\section{PENDAHULUAN}

Dislipidemia merupakan kelainan metabolisme lipid yang ditandai dengan peningkatan maupun penurunan kadar fraksi lipid dalam plasma. Kelainan fraksi lipid yang utama adalah kenaikan kolesterol total, kolesterol LDL, dan atau trigliserida dan serta penurunan kolesterol HDL (Arsana et al., 2019). Dislipidemia berperan utama dalam patogenesis terjadinya arterosklerosis pada dinding pembuluh darah yang merupakan penyebab terjadinya Penyakit Jantung Koroner (PJK) dan strok(Lin et al., 2018). Kedua penyakit ini merupakan penyebab utama kematian di dunia yaitu mencapai 17,3 juta dari 54 juta total kematian pertahun (WHO, 2014)(Benjamin et al., 2017). Tatalaksana terapi pasien dislipidemia terdiri dari terapi nonfarmakologis dan farmakologis. Terapi nonfarmakologis meliputi perubahan gaya hidup, olahraga sebagai aktivitas fisik, terapi nutrisi medis, penurunan berat badan dan penghentian merokok. Sedangkan terapi farmakologis dengan memberikan obat antilipid dan berpotensi memerlukan biaya yang sulit untuk dijangkau oleh seluruh masyarakat. Oleh sebab itu, pengobatan tradisional dengan pemanfaatan potensi tanaman khas Indonesia yang mempunyai kemampuan mengobati dan menurunkan kadar kolesterol darah perlu diteliti.

Masyarakat Indonesia sudah sejak jaman dahulu kala menggunakan ramuan obat tradisional sebagai upaya pemeliharaan kesehatan, pencegahan penyakit, dan perawatan kesehatan. Ramuan obat tradisional Indonesia tersebut dapat berasal dari tumbuhan, hewan, dan mineral, namun umumnya yang digunakan berasal dari tumbuhan. Perkembangan pelayanan kesehatan tradisional menggunakan ramuan ini kian pesat, terbukti dari hasil Riset Kesehatan Dasar (Riskesdas) 2013 bahwa persentase penduduk Indonesia yang pernah mengonsumsi jamu sebanyak 59,12 \% yang terdapat pada kelompok umur di atas 15 tahun, baik laki-laki maupun perempuan, di pedesaan maupun di perkotaan, dan 95,60\% merasakan manfaatnya (Kemenkes Indonesia, 2017). Salah satu tanaman yang secara empiris banyak digunakan untuk pengobatan adalah ketumbar (Coriandrum sativum $L$. ). Dari hasil penelitian sebelumnya diketahui beberapa khasiat dari ketumbar, diantaranya : aktivitas biologis ketumbar dapat merangsang enzim pencernaan dan peningkatan fungsi hati (Nyakudya et al., 2014). Minyak atsiri pada biji ketumbar juga memiliki sifat antimikroba terhadap spesies patogen seperti Salmonella (Mandal and Mandal, 2015). Pada penelitian lainnya juga ditemukan efektifitas rendaman biji ketumbar terhadap masalah keputihan pada wanita usia subur (Prastika,D.A, dan Sugita, 2018). Komponen aktif pada ketumbar adalah sabinene, myrcene, alfaterpinene, ocimene, linalool, geraniol, dekanal, desilaldehida, trantridecen, asam petroselinat, asam oktadasenat, d-mannite, skopoletin, $p$ simena, kamfena, dan felandren. Komponenkomponen tersebutlah yang menyebabkan ketumbar memiliki efek yang baik sebagai komponen obat. Dari kajian efektifitas tumbuhan ketumbar ditemukan senyawa flavonoid yang diduga berpotensi menurunkan kolesterol (AlSnafi, 2016).

Pada beberapa penelitian telah dilakukan pembuktian aktivitas hiperlipidemia pada tanaman herbal dengan menggunakan hewan percobaan yang diinduksi sehingga menjadi permodelan secara in vivo keadaan hiperlipidemia maupun diabetes.(Anioke et al., 2017) Induksi hewan percobaan dilakukan dengan berbagai metode penginduksian (G. Vijay Kumar, 2016). Ditemukan beberapa ekstrak tanaman herbal yang memiliki aktivitas antihiperlipidemia dengan adanya penurunan profil lipid yang signifikan pada hewan uji, dan aktivitas yang dihasilkan dibandingkan dengan obat hyperlipidemia standar (Yunarto, Elya and Konadi, 2015). Hal ini menjadi acuan dilakukan pengembangan pada ekstrak tanaman lainnya dengan aktivitas antihiperlipidemia agar dapat digunakan sebagai terapi adjuvant untuk penyakit hiperlipidemia.

\section{METODE}

\section{Desain, tempat dan waktu}

Desain penelitian ini adalah true experimental dengan rancangan randomized pretest and pos-test controlled group design. Sampel yang digunakan dalam penelitian ini adalah ketumbar (Coriandrum sativum $L$ ) yang telah diidentifikasi dengan mencocokkan ciri-ciri morfologinya dengan pustaka tanaman. Penelitian dilakukan di Laboratorium Penelitian Akademi Kesehatan John Paul II Pekanbaru. dari bulan Juni-September 2020.

\section{Bahan dan Alat}

Bahan-bahan yang digunakan pada penelitian ini, yaitu ekstrak etanol biji ketumbar, pakan normal, PTU (Prophyl Thio Urasil) 0,01\%, CMC(Carboxil Metyl Celulose) 1\%, kertas saring, pereaksi Dragendroff, $\mathrm{HCl}(\mathrm{p})$, serbuk $\mathrm{Mg}, \mathrm{H} 2 \mathrm{SO} 4(\mathrm{p}), \mathrm{CH} 3 \mathrm{COOH}$ glasial, $\mathrm{FeCl} 3$ 1\%, etanol 96\% dan Pereaksi LiebermanBurchard, alumunium foil, kertas label,aquades, etanol $70 \%$, tisu, kapas. Alat-alat yang digunakan dalam penelitian ini yaitu bejana maserasi, lumpang alu, alat gelas, blender, neraca digital, rotary evaporator, lemari pendingin, 
cholesterol test strip, kandang mencit, gunting bedah, sonde oral mencit.

\section{Langkah-Langkah Penelitian Ekstraksi biji ketumbar}

Ketumbar dicuci dengan air bersih dan dikeringanginkan di ruangan selama 1-3 hari. Ketumbar kering diblender hingga diperoleh serbuk ketumbar. Kemudian serbuk ketumbar diekstraksi dengan cara maserasi (perendaman) sebanyak $600 \mathrm{~g}$ dalam etanol 96\% sebanyak 2 L pada suhu kamar dan dimasukkan dalam wadah tertutup. Proses maserasi dilakukan selama 3 hari dan dilakukan penyaringan dengan kertas saring untuk memperoleh maserat. Maserat yang diperoleh diuapkan hingga diperoleh ekstrak kental ketumbar. Selanjutnya dilakukan skrining fitokimia pada ekstrak kental biji ketumbar dan uji aktifitas dalam menurunkan kolesterol darah pada hewan uji (Kartika, 2016).

\section{Persiapan hewan uji}

Hewan uji diaklimatisasi (adaptasi/ penyesuaian dengan lingkungan) selama 7 hari. Selama proses aklimatisasi hewan uji diberi makan dan minum sebanyak 3 kali sehari. Pengaturan suhu ruang dengan kisaran $18-19^{\circ} \mathrm{C}$, kelembaban udara antara $30-70 \%$. Selama proses aklimatisasi hewan uji dijauhkan dari kebisingan.

\section{Induksi hiperkolesterolemia pada mencit \\ Pemberian pakan hiperkolesterol} dilakukan selama 30-40 hari, pakan hiperkolesterol terdiri dari 30 gram kuning telur puyuh, PTU (Propiltiourasil) $0.1 \%$ dan air sampai $1000 \mathrm{~mL}$ serta $5 \mathrm{~kg}$ pakan ayam broiler. Pembuatan pakan hiperkolesterol yaitu dengan cara PTU 100 mg dilarutkan ke dalam $1000 \mathrm{~mL}$ aquades, telur puyuh dilarutkan dengan larutan PTU yang sudah dibuat, pakan ini diberikan kepada mencit dengan masing-masing volume $0.5 \mathrm{ml}$ per mencit dengan cara disondekan/oral. Selanjutnya diberikan pakan ayam broiler untuk meningkatkan kadar kolesterol hewan uji. Setelah 30-40 hari, dilakukan pengecekan seluruh mencit untuk diketahui kolesterol mencit setelah pemberian pakan hiperkolesterol. Pengecekan kolesterol ini dilakukan dengan metode CHOD-PAP. Lalu diberikan perlakukan setiap harinya sesuai dengan kelompoknya. Pada hari ke 7 setelah perlakuan diukur kembali kadar kolesterol. Sebelum pengukuran kadar kolesterol, mencit dipuasakan selama 10-12 jam, pengukuran kolesterol mencit tersebut merupakan kolesterol total mencit setelah pakan hiperkolesterol.

\section{Uji aktifitas antihiperkolesterolemia}

Hewan uji terdiri dari 4 kelompok yaitu kontrol negatif (menggunakan akuades), kontrol positif (simvastatin $1.3 \mathrm{mg} / \mathrm{kg} \mathrm{BB}$ ), kelompok ekstrak biji ketumbar dosis $420 \mathrm{mg} / \mathrm{kg}$ BB serta kelompok ekstrak biji ketumbar dosis 840 mg/kg BB dalam bentuk ekstrak. Setiap hari semua mencit akan diberikan perlakuan sesuai dosis setiap kelompok. Pengukuran kadar kolesterol total darah dilakukan yaitu pada hari ke 0 (sebelum induksi),hari ke 30 - 40 (sesudah induksi) dan hari ke 7 (sesudah perlakuan).

\section{Pengolahan dan analisis data}

Data yang diperoleh berupa kadar kolesterol darah hewan uji sebelum induksi hiperkoleterol, kadar kolesterol sesudah induksi hiperkolesterol dan kadar kolesterol sesudah perlakuan. Data dianlisis secara statistik menggunakan SPSS 18 dan disajikan secara deskriptif dalam bentuk tabel.

HASIL

Tabel 1. Hasil Uji Fitokimia Ekstrak Biji ketumbar

\begin{tabular}{ll}
\hline Golongan senyawa & Sampel \\
\hline Alkaloid & positif \\
Flavonoid & positif \\
Saponin & positif \\
Triterpenoid & negatif \\
Steroid & positif \\
\hline
\end{tabular}

Hasil skrining fitokimia dengan metoda tabung menunjukkan adanya senyawa alkaloid, flavonoid, saponin dan steroid.

Tabel 2. Hasil pengukuran kadar rata-rata kolesterol darah $(\mathrm{mg} / \mathrm{dl}) \pm$ standard deviasi sebelum induksi

\begin{tabular}{lc}
\hline \multicolumn{1}{c}{ Nama kelompok } & Sebelum induksi \\
\hline Kontrol negatif & $132.8 \pm 19.82$ \\
Kontrol positif & $133.6 \pm 8.32$ \\
Ekstrak dosis $420 \mathrm{mg} / \mathrm{kg} \mathrm{BB}$ & $134.6 \pm 13.68$ \\
Ekstrak dosis $840 \mathrm{mg} / \mathrm{kg} \mathrm{BB}$ & $133.4 \pm 10.99$ \\
\hline Hasil pengukuran kadar kolesterol sebelum \\
induksi dapat dilihat pada Tabel 2. Berdasarkan \\
hasil analisis statistik Anova dan uji lanjutannya \\
p >0,10 menunjukkan tidak ada perbedaan yang \\
signifikan kadar rata-rata kolesterol antar \\
kelompok
\end{tabular}


Tabel 3. Hasil pengukuran kadar rata-rata kolesterol darah $(\mathrm{mg} / \mathrm{dl}) \pm$ standard deviasi sesudah induksi

\begin{tabular}{lc}
\hline \multicolumn{1}{c}{ Nama kelompok } & Sesudah induksi \\
\hline Kontrol negatif & $201.8 \pm 6.57$ \\
Kontrol positif & $200.6 \pm 14.06$ \\
Ekstrak dosis $420 \mathrm{mg} / \mathrm{kg} \mathrm{BB}$ & $200.3 \pm 8.80$ \\
Ekstrak dosis $840 \mathrm{mg} / \mathrm{kg} \mathrm{BB}$ & $201.4 \pm 14.11$ \\
\hline
\end{tabular}

Pada Tabel 3. menunjukkan dimana kadar ratarata kolesterol tertinggi terdapat pada kelompok kontrol negatif yaitu $201.8 \mathrm{mg} / \mathrm{dl}$. Kemudian diikuti kelompok ekstrak dosis $840 \mathrm{mg} / \mathrm{kg}$ BB yaitu $201.4 \mathrm{mg} / \mathrm{dl}$ dan kelompok kontrol positif serta kelompok ekstrak dosis $420 \mathrm{mg} / \mathrm{kg}$ BB masing-masing yaitu 200.3 dan $199.6 \mathrm{mg} / \mathrm{dl}$.

Tabel 4. Hasil paired sample t test kadar kolesterol setelah induksi terhadap kadar kolesterol sebelum induksi masing-masing kelompok dan rata-rata selisih sesudah induksi dengan sebelum induksi.

\begin{tabular}{lcc}
\hline \multicolumn{1}{c}{ Kelompok } & Sig (2-tailed) & $\begin{array}{c}\text { kadar kolesterol sesudah induksi - sebelum } \\
\text { induksi (mg/dl) dan standar deviasi }\end{array}$ \\
\hline Kontrol negatif & 0.001 & $69 \pm 16.01$ \\
Kontrol positif & 0.000 & $67 \pm 13.80$ \\
Ekstrak dosis 420 mg/kg BB & 0.000 & $72 \pm 14.35$ \\
Ekstrak dosis $840 \mathrm{mg} / \mathrm{kg} \mathrm{BB}$ & 0.000 & $68,4 \pm 13$ \\
\hline
\end{tabular}

Berdasarkan hasil analisis statistik paired sample $t$ test (sig $<0.05$ ) yang tercantum pada tabel 4 menunjukkan bahwa seluruh kelompok uji mengalami kenaikan kadar kolesterol secara signifikan. Selanjutnya dilakukan analisi dengan Anova dan uji lanjutannya menggunakan data kadar rata-rata selisih kolesterol sesudah dan sebelum induksi pada tabel 4. menunjukkan tidak ada perbedaan yang signifikan kadar rata-rata selisih kolesterol antar kelompok setelah induksi.

Tabel 5. Hasil pengukuran rata-rata kolesterol darah $(\mathrm{mg} / \mathrm{dl}) \pm$ standard deviasi sesudah perlakuan

\begin{tabular}{lc}
\hline \multicolumn{1}{c}{ Nama kelompok } & Sesudah perlakuan \\
\hline Kontrol negatif & $192 \pm 8.27$ \\
Kontrol positif & $137 \pm 17.95$ \\
Ekstrak dosis $420 \mathrm{mg} / \mathrm{kg} \mathrm{BB}$ & $182.8 \pm 8.52$ \\
Ekstrak dosis $840 \mathrm{mg} / \mathrm{kg} \mathrm{BB}$ & $163.6 \pm 22.32$ \\
\hline
\end{tabular}

Hasil pengukuran kadar kolesterol hari ke 7 setelah perlakuan dapat dilihat pada tabel 5. Berdasarkan tabel 5. diketahui bahwa penurunan kadar kolesterol tertinggi adalah pada kelompok kontrol positif yaitu 137 $\mathrm{mg} / \mathrm{dl}$, kemudian diikuti kelompok kontrol ekstrak dosis $840 \mathrm{mg} / \mathrm{kg}$ BB yaitu $163.6 \mathrm{mg} / \mathrm{dl}$, dan kelompok ekstrak dosis $420 \mathrm{mg} / \mathrm{kg}$ BB yaitu $182.8 \mathrm{mg} / \mathrm{dl}$ serta kontrol negatif yaitu $192 \mathrm{mg} / \mathrm{dl}$.

Tabel 6. Hasil paired sample t test kadar kolesterol setelah perlakuan terhadap kadar kolesterol sebelum perlakuan masing-masing kelompok dan rata-rata selisih sesudah perlakuan dengan sebelum perlakuan.

\begin{tabular}{ccccc}
\hline Kelompok & $\begin{array}{c}\text { Uji } \\
\text { Homogenitas } \\
(\mathbf{s i g})\end{array}$ & $\begin{array}{c}\text { kadar kolesterol } \\
\text { sesudah perlakuan- } \\
\text { sebelum perlakuan } \\
(\mathbf{m g} / \mathbf{d l}) \text { dan standar } \\
\text { deviasi }\end{array}$ & $\begin{array}{c}\text { Uji Normalitas } \\
(\mathbf{s i g})\end{array}$ & $\begin{array}{c}\text { Anova One way } \\
\text { (sig) }\end{array}$ \\
\hline Kontrol negatif & & $9.8 \pm 2.38$ & \\
Kontrol positif & 0.054 & $63.6 \pm 10.18$ & 0.899 & 0.000 \\
Ekstrak dosis 420 & & $20.2 \pm 2.95$ & 0.828 & \\
mg/kg BB & & $39.4 \pm 9.45$ & 0.346 & \\
Ekstrak dosis 840 & & & 0.354 & \\
mg/kg BB & & &
\end{tabular}

Berdasarkan Tabel 6. pada uji homogenitas didapatkan nilai sig $(0.054)$ lebih besar dari $\alpha 0.05$ sehinga Ho diterima dan disimpulkan bahwa variasi antar kelompok sama atau homogen. Dari tabel 6. juga dapat lihat pada uji normalitas setiap kelompok didapatkan nilai sig > 0.05 yang berarti data terdistribusi normal. Pada uji Anova One way didapatkan nilai sig (0.000) sehingga Ho ditolak dan dapat disimpulkan bahwa terdapat perbedaan rata-rata 
penurunan kadar kolesterol dalam darah pada setiap kelompok perlakuan. Pada penelitian ini terdapat 4 kelompok perlakuan sehingga perlu diketahui kelompok yang dapat dinyatakan berbeda secara signifikan. Pada uji post-hoc diketahui kelompok kontrol positif (simvastatin) dan kelompok ekstrak dosis $840 \mathrm{mg} / \mathrm{kg}$ BB mengalami penurunan kadar kolesterol secara signifikan terhadap seluruh kelompok. Sementara itu kelompok kontrol negatif jika dibandingkan dengan kelompok ekstrak dosis $420 \mathrm{mg} / \mathrm{kg}$ BB perbedaan penurunan kadar kolesterol tidak signifikan Jika dibandingkan kelompok ekstrak $420 \mathrm{mg} / \mathrm{kg}$ BB terhadap kelompok ekstrak $840 \mathrm{mg} / \mathrm{kg}$ BB terdapat perbedaan penurunan kolesterol yang signifkan. Hal ini menunjukkan bahwa pada penelitian ini peningkatan dosis menimbulkan peningkatan efek antihiperkolesterolemia. kontrol positif jika dibandingkan dengan kelompok ekstrak dosis $840 \mathrm{mg} / \mathrm{kg}$ BB perbedaan penurunan kadar kolesterol signifikan, hal ini menyatakan kemampuan ekstrak dosis $840 \mathrm{mg} / \mathrm{kg}$ BB dalam menurunkan kolesterol lebih rendah dibandingkan simvastatin sebagai kontrol positif.

\section{PEMBAHASAN}

Skrining fitokimia bertujuan untuk mengetahui senyawa metabolit sekunder yang terdapat dalam biji ketumbar. Ketumbar (Coriandrum sativum) merupakan tumbuhan rempah-rempah yang populer di Indonesia. Manfaat yang diambil dari ketumbar adalah bagian daun, biji dan buah. Dari semua kandungan terdapat vitamin, mineral dan zat besi pada bagian daunnya, sedangkan pada bagian biji mengandung minyak atsiri seperti linalool $70 \%$ Selain itu terdapat senyawa monoterpen, phenolic acids, steroids dan flavonoids(S. Bhat, P. Kaushal, 2014). Identifikasi alkaloid dilakukan menggunakan pereaksi Mayer membentuk endapan putih atau krem. Pada uji flavonoid menggunakan $\mathrm{HCL}$ dan logam $\mathrm{Mg}$ sehingga terbentuknya warna merah jingga akibat tereduksinya inti benzopiron. Saponin ditemukan dengan terbentuknya busa karena glikosida yang terkandung pada ekstrak terhidrolisis membentuk glukosa dan senyawa lainnya(Dian Riana Ningsih, Zusfahair, 2016). Sementara itu untuk uji steroid dilakukan dengan cara ekstrak dilarutkan dalam kloroform kemudian ditambah pereaksi LiebermannBouchard (asam asetat anhidrat-asam sulfat) menunjukkan hasil positif dengan adanya perubahan warna menjadi biru.

Induksi hiperkolesterol menggunakan diet tinggi lemak menyebabkan kenaikan kolesterol mencit pada semua kelompok (tabel
4), hasil paired sample $t$ test ( sig $<0.05$ ) menunjukkan kenaikan kadar kolesterol secara signifikan. Berdasarkan hasil uji ANOVA, tidak ada perbedaan nyata kadar kolesterol pada seluruh mencit setelah induksi hiperkolesterol. Hal ini disebabkan semua hewan uji diberi perlakuan yang sama yaitu diberikan diet tinggi lemak berupa kuning telur puyuh, PTU dan pakan ayam broiler. Pada penelitian ini ekstrak dosis $420 \mathrm{mg} / \mathrm{kg}$ BB sudah dapat menurunkan kadar kolesterol mencit tetapi tidak cukup signifikan jika dibandingkan dengan kelompok kontrol negatif. Penurunan kolesterol rata-rata pada kelompok ekstrak dosis $420 \mathrm{mg} / \mathrm{kg}$ BB adalah 20,2 mg/dl. Pada ekstrak dosis $840 \mathrm{mg} / \mathrm{kg}$ BB penurunan kadar kolesterol total mencapai 39,4 mg/dl yang cukup signifikan jika dibandingkan dengan kelompok kontrol negatif dan kelompok ekstrak dosis 420mg/kg BB. Dengan demikian pada penelitian ini peningkatan dosis menimbulkan peningkatan efek antihiperkolesterolemia Akan tetapi penurunan kadar kolesterol pada kelompok ekstrak dosis $840 \mathrm{mg} / \mathrm{kg}$ BB belum mencapai kemampuan kelompok kontrol positif (simvastatin) dalam menurunkan kolesterol darah mencit. Selain ketumbar ada beberapa tumbuhan lain yang masih termasuk famili Asteraceae yang telah diteliti dan juga memiliki efek menurunkan kolesterol pada tikus yaitu daun kenikir (Cosmos caudatus Kunth) (Tandi, Ayu and Nobertson, 2017) dan daun afrika (Vernonia amygdalina Del.) (Ardiani, 2017).

Ekstrak biji ketumbar (Coriandrum sativum L.) dapat menurunkan kadar kolesterol pada mencit swiss webster jantan, hal ini didukung oleh adanya kandungan kimia yang terdapat di dalam ekstrak salah satunya flavonoid. Senyawa flavonoid dapat menurunkan kadar kolesterol total dengan mekanisme kerja menghambat 3-Hydroxy-3-Methyl-GlutarylCoenzymeA (HMG-CoA) reduktase yang menyebabkan penurunan sintesis kolesterol. Selain itu juga menyebabkan peningkatkan jumlah reseptor LDL yang terdapat di dalam membran sel hepar dan jaringan ekstrahepatik sehingga kadar kolesterol total akan menurun, dengan penurunan kadar kolesterol total tersebut maka LDL yang berfungsi sebagai alat pengangkut lipid di dalam darah akan berkurang kadarnya(Sri Mutia, 2018). Seperti pada flavonoid, alkaloid bekerja sebagai antioksidan dengan mendonorkan ion hidrogen Hal ini dapat menghambat aktivitas enzim lipase pankreas sehingga meningkatkan sekresi lemak melalui feses; akibatnya penyerapan lemak oleh hati terhambat sehingga tidak dapat diubah menjadi kolesterol (Artha, Mustika and Sulistyawati, 
2017) Menurut (Ekananda, 2015) mekanisme saponin dalam menurunkan kolesterol dalam darah yaitu saponin dapat menghambat penyerapan kolesterol dan trigliserida dengan membentu ikatan kompleks di dalam usus dan tidak larut dalam kolesterol, berikatan dengan asam empedu membentuk misel dan meningkatkan pengikatan kolesterol dan trigliserida oleh serat.

\section{KESIMPULAN}

Ekstrak etanol biji ketumbar (Coriandrum sativum L.) memiliki efektifitas dalam menurunkan kolesterol total pada mencit swiss webster jantan, dan dosis yang paling efektif sebagai antihiperkoleterolemia yaitu dosis $840 \mathrm{mg} / \mathrm{kg} \mathrm{BB}$.

\section{SARAN}

Perlu dilakukan penelitian lebih lanjut mengenai senyawa yang terkandung di dalam ekstrak etanol biji ketumbar terutama jenis flavonoid yang diduga memiliki aktivitas sebagai antikolesterol.

\section{UCAPAN TERIMA KASIH}

Ucapan terima kasih kepada Direktorat Pendidikan Tinggi Kementrian Pendidikan dan Kebudayaan Republik Indonesia atas dana hibah yang diberikan untuk melakukan penelitian ini, dan juga kepada Direktur Akademi Kesehatan John Paul II Pekanbaru yang telah mengizinkan penulis untuk melakukan kegiatan penelitian serta semua pihak yang telah membantu kesuksesan penelitian ini.

\section{DAFTAR PUSTAKA}

Al-Snafi, P. D. A. E..2016. 'A review on chemical constituents and pharmacological activities of Coriandrum sativum', IOSR Journal of Pharmacy (IOSRPHR), 06(07), pp. 17-42. doi: 10.9790/3013-067031742.

Anioke, I. et al. 2017. 'Investigation into hypoglycemic, antihyperlipidemic, and renoprotective potentials of dennettia tripetala (Pepper Fruit) seed in a rat model of diabetes', BioMed Research International, 2017. doi: $10.1155 / 2017 / 6923629$.

Ardiani, R. 2017. 'Efek Antikolesterol Ekstrak Etanol Daun Afrika ( Vernonia amygdalina Del .) Pada Tikus', Jurnal Penelitian Pendidikan MIPA, 2(1), pp. 153-158.

Arsana, P. M. et al. 2019. Pedoman
Pengelolaan Dislipidemi di Indonesia 2019, Pb. Perkeni. doi: 10.1002/bit.22430.

Artha, C., Mustika, A. and Sulistyawati, S. W. 2017. 'Pengaruh Ekstrak Daun Singawalang Terhadap Kadar LDL Tikus Putih Jantan Hiperkolesterolemia', eJournal Kedokteran Indonesia, 5(2), pp. 105-109. doi: 10.23886/ejki.5.7151.

Benjamin, E. J. et al. 2017. Heart Disease and Stroke Statistics'2017 Update: A Report from the American Heart Association, Circulation. doi: 10.1161/CIR.0000000000000485.

Dewi Andang Prastika dan Sugita 2018. 'Efektifitas Rendaman Biji ketumbar ( Coriandrum sativum L)untuk Terapi Masalah Keputihan pada Wanita Usia Subur', Jurnal Terpadu Ilmu Kesehatan, 7(1).

Dian Riana Ningsih, Zusfahair, D. K. 2016. 'Identifikasi Senyawa Metabolit Sekunder Serta Uji Aktivitas Ekstrak daun Sirsak Sebagai Antibakteri', Molekul, 11(1), p. 2016.

Ekananda, N. A. 2015. '[Artikel Review] Bay Leaf in Dyslipidemia Therapy', Dyslipidemia Therapy J MAJORITY |, 4(4), p. 64. Available at: https://juke.kedokteran.unila.ac.id/index. $\mathrm{php/majority/article/view/580.}$

G. Vijay Kumar, N. D. 2016.

'Antihyperlipidemic Activity of Leaf', 2016(3), pp. 408-413.

Kartika, R. 2016. 'Pengaruh Pemberian Ekstrak Etanol Daun Kecapi ( Sandoricum koetjape ( Burm . f .) Merr .) Terhadap Penurunan Kadar Kolesterol Total pada Mencit Jantan ( Mus musculus )', Jurnal Kimia Mulawarman, 13(2), pp. 64-67.

Kemenkes Indonesia 2017. Keputusan Mentri Kesehatan Republik IndonesiaNo HK.01.07/MENKES/187/2017 Tentang Formularium Ramuan Obat tradisional Indonesia.

Lin, C. F. et al. 2018. 'Epidemiology of Dyslipidemia in the Asia Pacific Region', International Journal of Gerontology, 12(1), pp. 2-6. doi: 10.1016/j.ijge.2018.02.010.

Mandal, S. and Mandal, M. 2015. 'Coriander (Coriandrum sativum L.) essential oil: Chemistry and biological activity', Asian 
Pacific Journal of Tropical Biomedicine, 5(6), pp. 421-428. doi:

10.1016/j.apjtb.2015.04.001.

Nyakudya, T. et al. 2014. 'Dietary

supplementation with coriander (Coriandrum sativum) seed: Effect on growth performance, circulating metabolic substrates, and lipid profile of the liver and visceral adipose tissue in healthy female rats', International Journal of Agriculture and Biology, 16(1), pp. 125-131.

S. Bhat, P. Kaushal, M. K. and H. K. S. 2014. 'Coriander (Coriandrum sativum L.): Processing, nutritional and functional aspects', African Journal of Plant Science, 8(1), pp. 25-33. doi: 10.5897/ajps2013.1118.

Sri Mutia, F. dan Z. T. 2018. 'Jurnal bioleuser', Jurnal Bioleuser, 2(1), pp. 20-23.

Available at:

http://www.jurnal.unsyiah.ac.id/bioleuser
I.

Tandi, J., Ayu, G. and Nobertson, R. 2017. 'Uji Efek Ekstrak Etanol Daun Kenikir (Cosmos caudatus Kunth.) Terhadap Penurunan Kadar Kolesterol Pada Tikus Wistar (Rattus norvegicus) Hiperkolesterolemia-Diabetes', Farmakologika: Jurnal Farmasi, 14(2), pp. 112-118.

WHO 2014. A wealth of information on global public health, World Health Organization. doi: WHO/HIS/HSI/14.1.

Yunarto, N., Elya, B. and Konadi, L. 2015. 'Potensi Fraksi Etil Asetat Ekstrak Daun Gambir ( Uncaria gambir Roxb .) sebagai Antihiperlipidemia Potency of Ethyl Acetate Fraction of Gambier Leaves Extract Abstrak mengandung katekin adalah gambir Alat dan bahan ini adalah rotary evaporator ( Buchi )', Jurnal Kefarmasian Indonesia, 5(1), pp. 1-10.

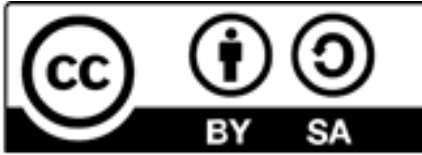

